\title{
POTENSI ERIONOTA THRAX SEBAGAI AGEN PENYEBAR PATOGEN PENYEBAB PENYAKIT LAYU BAKTERI PADA TANAMAN PISANG (BLOOD DISEASE BACTERIUM)
}

\author{
Radix Suharjo $^{1}$, Edhi Martono ${ }^{2}$, dan Siti Subandiyah ${ }^{2}$
}

\begin{abstract}
Potential of Erionota thrax to spread the causal agen of banana bacterial wilt (Blood Disease Bacterium). This study was conducted in Gerbosari, Samigaluh, Kulonprogo, Yogyakarta and in the Laboratory of Bacteriology and Entomology, Faculty of Agriculture, Gadjah Mada University, Yogyakarta during December 2002 to June 2003. The aim of this study was to find out the potency of Erionota thrax to spread Blood Disease Bacterium the causal agent of banana blood disease in Indonesia. A field survey was conducted to record the existance of Blood Disease Bacterium in larvae and adult E. thrax. The results show that Blood Disease Bacterium was not found in the larval stage of $E$. thrax. In the adult of $E$. thrax, the pathogen was found on the legs, wings, body surface, head and head surface, but it was not found inside the body of $E$. thrax.
\end{abstract}

Key words : Erionota thrax, Banana, Blood Disease Bacterium

\section{PENDAHULUAN}

Tanaman pisang mempunyai potensi ekonomi yang tinggi apabila dikelola secara intensif yang berorientasi agribisnis. Dewasa ini pisang telah menjadi mata dagang ekspor dan impor di pasar internasional (Rukmana, 1999). Walaupun begitu, di Indonesia tanaman pisang ditanam dengan input produksi dan perhatian yang minim. Kondisi inilah yang menyebabkan usaha untuk meningkatkan produksi tanaman pisang menjadi lebih sulit. Padahal tanaman ini dapat tumbuh di setiap tempat, baik di pekarangan sekitar rumah dan di lahan-lahan sawah (Subandiyah et al., 2005). Di samping cara budidayanya yang kurang baik tersebut, permasalahan hama dan penyakit tanaman juga menjadi kendala tersendiri dalam usaha meningkatkan produksi tanaman pisang.

Penyakit layu bakteri merupakan salah satu penyakit yang menyerang pertanaman pisang disamping penyakit layu Fusarium dan Sigatoka. Penyebaran penyakit ini dapat terjadi melalui bibit (anakan pisang), tanah, alat-alat pertanian dan serangga (Suspendy, 2001). Anonimous (1971) melaporkan bahwa serangga-serangga yang mengunjungi bunga pisang menjadi agen utama dalam penyebaran patogen penyebab layu bakteri. Ada beberapa jenis serangga yang berpotensi sebagai agen penyebar penyakit layu bakteri antara lain serangga dari ordo Hymenoptera (Apidae), Diptera (Chloropidae, Scaaridae, Sarchopagidae,
Antomyidae, Platyzidae, Tephritidae, Drosophilidae, Muscidae, Syrphidae, Culicidae), Lepidoptera (Coleophoridae), Blattaria, (Blattidae) (Suspendy, 2001; Supriadi, 2005).

Subandiyah, et al. (2005) melaporkan ada dua spesies serangga dominan di daerah pertanaman pisang di Yogyakarta yang mempunyai intensitas penyakit darah pisang yang tinggi. Serangga tersebut adalah Erionota thrax (Lepidoptera) dan Cosmopolites sordidus (Coleoptera). Penelitian tentang peranan dua serangga tersebut, khususnya Erionota thrax dalam penyebaran penyakit darah pisang belum pernah dilaporkan. Oleh karena itu, maka dianggap perlu untuk melakukan penelitian tentang kemampuan E. thrax sebagai agen penyebar bakteri penyebab penyakit darah pisang.

\section{METODE PENELITIAN}

Penelitian ini dilaksanakan pada bulan Desember 2002 sampai Juni 2003. Pengambilan sampel larva dan imago Erionota thrax dilakukan di Desa Gerbosari, Samigaluh, Kulon Progo Yogyakarta yang merupakan daerah endemik penyakit layu bakteri tanaman pisang. Identifikasi $E$. thrax dilakukan di Laboratorium Entomologi. Sedangkan isolasi dan identifikasi Blood Disease Bacterium (BDB) dilakukan di laboratorium Bakteriologi, Jurusan Perlindungan Tanaman, Fakultas Pertanian Universitas Gadjah Mada Yogyakarta.

\footnotetext{
${ }^{1}$ Dosen Jurusan Proteksi Tanaman, Fakultas Pertanian, Universitas Lampung, email : radix_suharjo@yahoo.com

${ }^{2}$ Dosen Jurusan Perlindungan Tanaman, Fakultas Pertanian, Universitas Gadjah Mada, Yogyakarta
} 


\section{Penangkapan Erionota thrax}

Penangkapan E. thrax dilakukan dengan menggunakan jala (jaring serangga) yang dilakukan pada awal pagi hari (pukul 05.00 WIB - 06.30 WIB) ataupun senja hari (pukul 17.30 WIB - 18.30 WIB) pada tanaman pisang yang berbunga. Identifikasi E. thrax mengacu pada Borror et al. (1981), Anonimous (1991) dan Kalshoven (1981).

\section{Isolasi Fase Larva E. thrax \\ Isolasi bagian luar tubuh. Isolasi dilakukan dengan cara mencuci larva dengan larutan PBS 0,02 M, pH 7,2 dengan cara $1 \mathrm{gr}$ berat tubuh dicuci dengan $9 \mathrm{ml}$ PBS dan kemudian air hasil cuciannya digoreskan pada media Casamino Acid Pepton Glucose (CPG) dengan menggunakan jarum ose. Pengamatan terhadap ciri-ciri koloni bakteri penyebab penyakit darah pisang dilakukan setelah biakan berumur 48-72 jam.}

Isolasi bagian dalam tubuh. Tubuh larva E. thrax yang diperoleh dari lapang didisinfeksi dengan larutan Natrium Hipoklorit 1\% selama 1 jam. Setelah itu dicuci dengan air steril 3-4 kali kemudian ditiriskan dan digerus sampai hancur, lalu ditambahkan PBS $0,02 \mathrm{M}, \mathrm{pH} 7,2$ dengan cara seperti pada isolasi bagian tubuh luar larva. Setelah itu, ekstraknya digoreskan pada media CPG dengan menggunakan jarum ose. Pengamatan terhadap ciri-ciri koloni bakteri penyebab penyakit darah pisang dilakukan setelah biakan berumur 48-72 jam.

\section{Isolasi Fase Imago E. thrax}

Isolasi $B D B$ dari imago $E$. thrax dilakukan pada bagian kepala (luar dan dalam kepala), sayap, kaki dan tubuh (dalam tubuh dan luar tubuh) imago termasuk bagian torak.

\section{Isolasi bagian kepala}

Isolasi bagian luar kepala. Isolasi dilakukan dengan cara memotong bagian kepala imago, kemudian mencuci bagian kepala dengan larutan PBS 0,02 M, $\mathrm{pH} 7,2$ dengan cara 1 gr berat dicuci dengan $9 \mathrm{ml}$ PBS. Setelah itu air hasil cuciannya digoreskan pada media CPG dengan menggunakan jarum ose. Pengamatan terhadap ciri-ciri koloni bakteri penyebab penyakit darah pisang dilakukan setelah biakan berumur 48-72 jam.

Isolasi bagian dalam kepala. Kepala E. thrax yang diperoleh didisinfeksi dengan larutan Natrium
Hipoklorit 1\% selama 1 jam. Setelah itu dicuci dengan air steril 3-4 kali kemudian ditiriskan dan digerus sampai hancur, lalu ditambahkan PBS 0,02 M, pH 7,2 dengan cara seperti pada isolasi bagian luar kepala serangga. Setelah itu ekstraknya digoreskan pada media CPG dengan menggunakan jarum ose. Pengamatan terhadap ciri-ciri koloni bakteri penyebab penyakit darah pisang dilakukan setelah biakan berumur 48-72 jam.

\section{Isolasi bagian sayap}

Bagian sayap imago yang diperoleh dipotong, kemudian dicuci dengan larutan PBS 0,02 M, pH 7,2 dengan cara $1 \mathrm{gr}$ berat dicuci dengan $9 \mathrm{ml}$ PBS dan kemudian air hasil cuciannya digoreskan pada media CPG dengan menggunakan jarum ose. Pengamatan terhadap ciri-ciri koloni bakteri penyebab penyakit darah pisang dilakukan setelah biakan berumur 48-72 jam.

\section{Isolasi dari kaki}

Bagian kaki imago dipotong, kemudian dicuci dengan larutan PBS 0,02 M, pH 7,2 dengan cara 1 gr berat dicuci dengan $9 \mathrm{ml}$ PBS dan kemudian air hasil cuciannya digoreskan pada media CPG dengan menggunakan jarum ose. Pengamatan terhadap ciriciri koloni bakteri penyebab penyakit darah pisang dilakukan setelah biakan berumur 48-72 jam.

\section{Isolasi bagian tubuh}

Isolasi bagian luar tubuh. Tubuh E. thrax (tanpa kepala, sayap dan kaki) dicuci dengan larutan PBS $0,02 \mathrm{M}, \mathrm{pH}$ 7,2 dengan cara 1 gr berat dicuci dengan 9 ml PBS dan kemudian air hasil cuciannya digoreskan pada media CPG dengan menggunakan jarum ose. Pengamatan terhadap ciri-ciri koloni bakteri penyebab penyakit darah pisang dilakukan setelah biakan berumur 48-72 jam.

Isolasi bagian dalam tubuh. Tubuh E. thrax (tanpa kepala, sayap dan kaki) yang ada didisinfeksi dengan larutan Natrium Hipoklorit 1\% selama 1 jam. Setelah itu dicuci dengan air steril 3-4 kali kemudian ditiriskan dan digerus sampai hancur, lalu ditambahkan PBS 0,02 M, pH 7,2 dengan cara seperti pada isolasi bagian luar kepala serangga. Setelah itu ekstraknya digoreskan pada media CPG dengan menggunakan jarum ose. Pengamatan terhadap ciriciri koloni bakteri penyebab penyakit darah pisang dilakukan setelah biakan berumur 48-72 jam. 


\section{Uji Reaksi Hipersensitif}

Uji reaksi hipersensitif dilakukan dengan menyuntikkan 300 mikroliter suspensi koloni bakteri yang diduga sebagai koloni $B D B$ pada permukaan bawah daun tanaman tembakau. Hasil negatif pada uji gram dan hasil yang positif pada uji reaksi hipersensitif menunjukkan bahwa bakteri tersebut merupakan patogen tumbuhan dan dapat diduga bakteri tersebut merupakan $B D B$.

\section{Uji Patogenesitas}

Untuk lebih meyakinkan bahwa koloni bakteri tersebut merupakan $B D B$, maka koloni yang menunjukkan hasil positif pada uji reaksi hipersensitif dilakukan uji patogenesitas pada tanaman pisang. Pengujian dilakukan dengan menggunakan metode pelukaan akar yang mengacu pada metode Fahy \& Hayward (1983) dan Schaad et al. (2001) yang telah dimodifikasi.

Bibit tanaman pisang varietas kepok yang berumur 4 bulan akarnya dilukai (dipotong secukupnya) kemudian direndam dalam suspensi bakteri selama 30 menit. Setelah itu ditanam dalam polibag dan sebanyak $10 \mathrm{ml}$ suspensi bakteri disiramkan di sekitar tanaman pisang segera setelah ditanam. Pengamatan dilakukan terhadap gejala kelayuan yang muncul.

\section{HASIL DAN PEMBAHASAN}

\section{Penangkapan E. thrax}

Penangkapan E. thrax yang dilakukan dengan menggunakan jaring serangga berhasil memperoleh 15 ekor imago E. thrax. Hasil pengamatan menunjukkan bahwa $E$. thrax aktif mengunjungi bunga pisang hanya pada jam $05.30-06.00$ WIB (pagi hari) dan jam 17.30 - $18.00 \mathrm{WIB}$ (senja hari).

\section{Isolasi Blood Disease Bacterium (BDB) dari E. thrax}

Isolasi sebagai usaha untuk menemukan $B D B$ dilakukan pada dua fase hidup $E$. thrax, yaitu fase larva dan Imago. Hasil isolasi $B D B$ dari kedua fase hidup E. thrax tersebut dapat dilihat pada Tabel 1.

\section{Isolasi pada fase larva}

Isolasi dilakukan pada dua bagian tubuh larva, yaitu bagian permukaan tubuh dan dalam tubuh. Larva E. thrax (banana skipper, banana leaf roller) menyerang tanaman pisang dengan cara membuat gulungan pada daun pisang dan memakan daun tersebut dari dalam gulungan (Sunarjono et al., 1989; Kalshoven, 1981; Mau \& Kessing, 2003). Berdasarkan hal tersebut tersebut, ada kemungkinan bahwa BDB mampu berpindah dan bertahan hidup pada tubuh larva. Isolasi dilakukan pada 20 ekor larva yang diambil dari daerah penelitian.

Isolasi bagian permukaan tubuh larva. Hasil isolasi pada bagian permukaan tubuh larva menunjukkan hasil yang negatif. Pada daerah tersebut ternyata tidak ditemukan adanya $B D B$. Hal itu ditunjukkan dengan hasil negatif pada uji reaksi hipersensitif. Sedangkan, koloni $B D B$ akan menunjukkan reaksi positif pada uji

Tabel 1. Hasil isolasi Blood Disease Bacterium dari fase larva dan imago Erionota thrax

\begin{tabular}{llc}
\hline Sumber isolasi & Bagian yang diisolasi & $\begin{array}{c}\text { Keberadaan Blood Disease Bacterium } \\
(\text { BDB })\end{array}$ \\
\hline Larva E. thrax & Permukaan Tubuh & - \\
& Dalam tubuh & - \\
Imago E. thrax & Permukaan kepala & + \\
& Dalam Kepala & + \\
& Sayap & + \\
& Kaki & + \\
& Permukaan tubuh & + \\
& Dalam tubuh & - \\
\hline
\end{tabular}

Ket :

- Tidak ditemukan BDB.

+ Ditemukan BDB. 
reaksi hipersensitif pada daun tanaman tembakau (Schaad et al., 2001).

Isolasi bagian dalam tubuh larva. Sama seperti pada bagian permukaan tubuh larva, pada bagian ini juga tidak ditemukan adanya $B D B$, yang ditunjukkan dengan hasil yang negatif pada uji reaksi hipersensitif.

Tidak ditemukannya $B D B$ pada kedua bagian tubuh larva tersebut diduga terkait dengan cara menginfeksi bakteri tersebut. $B D B$ merupakan bakteri yang menyerang pembuluh xylem tanaman pisang yang terletak pada batang pisang (true stem). Gejala layu pada tanaman pisang yang terserang $B D B$ tampak karena adanya penyumbatan aliran air oleh Extracellular Polysaccharide (EPS) bakteri yang berada pada saluran xylem tanaman. Gejala layu yang tampak, itu terjadi karena minimnya suplai air dan nutrisi ke daun (Buddenhagen \& Kelman, 1964).

Ketidakberadaan $B D B$ pada larva E. thrax tersebut diduga karena aliran bakteri ini tidak sampai ke daerah helaian daun pisang. Namun begitu, masih perlu adanya penelitian lebih lanjut tentang adanya dugaan ini.

\section{Isolasi fase Imago}

Isolasi pada fase imago dibagi menjadi empat bagian tubuh, yaitu bagian kepala (permukaan dan dalam kepala), kaki, sayap dan tubuh (permukaan dan dalam tubuh) termasuk bagian torak. Isolasi dilakukan pada 15 ekor imago E. thrax yang berhasil ditangkap di daerah penelitian. Dari 15 ekor yang tertangkap ternyata 9 diantaranya terbukti membawa bakteri penyebab penyakit darah pisang.

Dalam mencari nektar, E. thrax akan mengunjungi bunga pisang yang seludangnya sudah mulai terbuka, ataupun pada bunga pisang yang seludangnya sudah terbuka, namun masih terdapat bunga pisang jantan yang menempel pada buah pisang.

Untuk mendapatkan nektar, E. thrax akan masuk ke dalam seludang yang sudah membuka dan akan hinggap pada bunga pisang. Hal ini akan membuka peluang bagi $B D B$ untuk dapat berpindah ke seluruh permukaan tubuh $E$. thrax dan selanjutnya berpindah dari permukaan tubuh ke bunga pisang yang lain.

\section{Isolasi bagian kepala}

Permukaan kepala. Hasil isolasi menunjukkan terdapat koloni bakteri yang memiliki ciri-ciri koloni seperti $B D B$ (Gambar 1). Untuk lebih meyakinkan bahwa koloni tersebut merupakan koloni $B D B$, maka dilakukan uji gram (KOH 3\%), uji reaksi hipersensitif dan uji patogenesitas.

Uji gram menunjukkan bahwa bakteri tersebut bersifat gram negatif. Uji reaksi hipersensitif dan uji patogenesitas menunjukkan hasil yang positif (Gambar 2 dan Tabel 2). Hal itu membuktikan bahwa koloni bakteri tersebut merupakan koloni $B D B$, bakteri penyebab penyakit darah pisang.
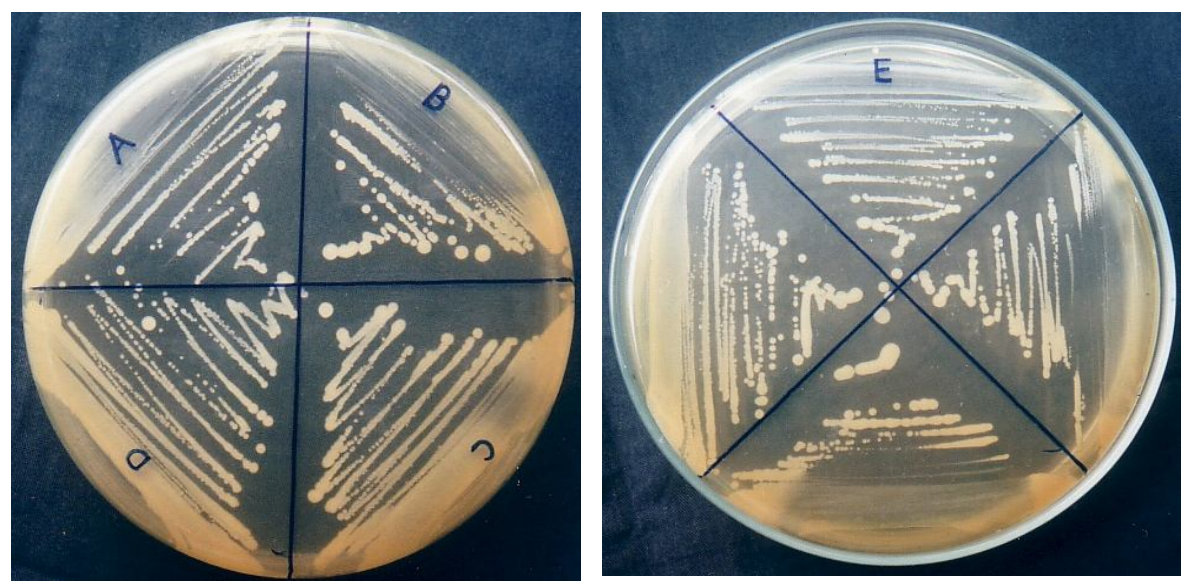

Gambar 1. Koloni bakteri yang diisolasi dari imago E. thrax pada bagian kaki (A), Dalam Kepala (B), Permukaan Tubuh (C), Permukaan Kepala (D) dan Sayap (E) setelah inkubasi selama 48 jam. 

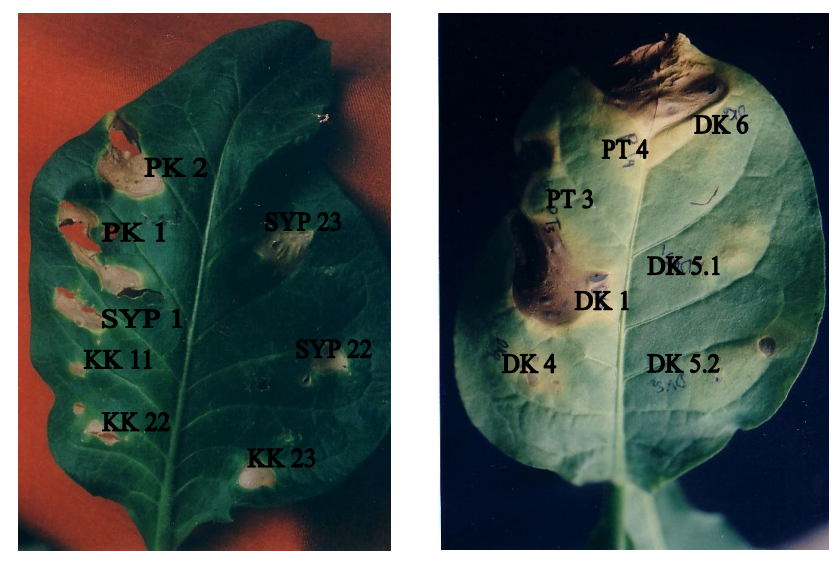

$\boldsymbol{a}$

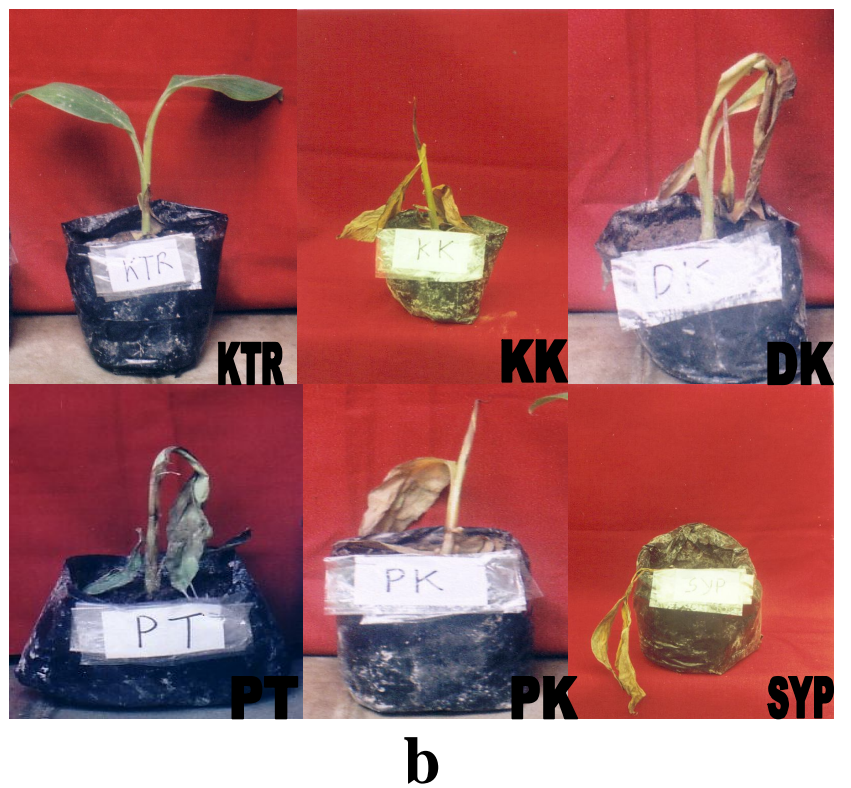

Gambar 2. Hasil uji reaksi hipersensitif dan patogenesitas koloni bakteri yang diisolasi dari imago E. thrax .

a. Hasil uji reaksi hipersensitif; bagian kaki (KK), dalam kepala (DK), permukaan tubuh (PT), permukaan kepala (PK) dan sayap (SYP) pada daun tanaman tembakau 4 - 5 hari setelah inokulasi.

b. Hasil uji patogenesitas; kontrol (KTR), bagian kaki (KK), dalam kepala (DK), permukaan tubuh (PT), permukaan kepala (PK) dan sayap (SYP) pada bibit tanaman pisang varietas kepok hasil kultur jaringan umur 4 bulan $5-10$ hari setelah inokulasi.

Tabel 2. Hasil uji gram, uji reaksi hipersensitif dan uji patogenesitas koloni bakteri pada imago

\begin{tabular}{lccc}
\hline Bagian Tubuh & Uji gram (sifat gram) & Reaksi Hipersensitif & Uji Patogenesitas \\
\hline Permukaan Kepala & Negatif & Positif & Positif \\
Dalam Kepala & Negatif & Positif & Positif \\
Sayap & Negatif & Positif & Positif \\
Kaki & Negatif & Positif & Positif \\
Permukaan Tubuh & Negatif & Positif & Positif \\
Dalam Tubuh & Negatif & Negatif & - \\
\hline
\end{tabular}


Dalam kepala. Isolasi dilakukan untuk mengetahui apakah BDB dapat masuk dan bertahan pada saluran ludah E. thrax. Hasil isolasi menunjukkan bahwa pada daerah ini juga ditemukan koloni bakteri tersebut.

Kenyataan ini membuktikan bahwa $B D B$ mampu masuk dan bertahan di dalam saluran ludah E. thrax. Walaupun demikian masih perlu adanya penelitian lebih lanjut, sejauh manakah $B D B$ dapat bertahan di saluran ludah $E$. thrax tersebut.

Masuknya bakteri ke dalam saluran ludah E. thrax diduga terhisap pada waktu serangga ini mencari nektar. Bakteri yang terhisap tersebut secara otomatis akan bercampur dengan air liur E. thrax. Bercampurnya bakteri dengan air liur ini merupakan media efektif bagi bakteri tersebut untuk dapat berpindah ke inang berikutnya, karena air liur ini akan selalu dikeluarkan oleh $E$. thrax setiap kali serangga ini menghisap nektar.

Isolasi bagian sayap. Hasil isolasi pada bagian sayap menunjukkan hasil yang sama dengan hasil isolasi pada bagian permukaan dan dalam kepala E. thrax. Pada bagian ini juga ditemukan adanya koloni BDB.

Isolasi bagian kaki. Sama halnya seperti hasil isolasi pada bagian sayap dan kepala, pada bagian kaki ini juga ditemukan adanya koloni $B D B$.

\section{Isolasi bagian tubuh $E$. thrax}

Permukaan tubuh. Isolasi pada bagian permukaan tubuh menunjukkan hasil yang sama dengan hasil isolasi pada beberapa bagian tubuh $E$. thrax yang lain. Pada bagian ini juga ditemukan adanya koloni BDB.

Dalam tubuh. Pada bagian dalam tubuh E. thrax ternyata tidak ditemukan adanya koloni BDB. Hal ini dibuktikan dengan hasil yang negatif pada uji reaksi hipersensitif. Kenyataan ini membuktikan bahwa bakteri tersebut bersifat non persisten (Maryam et al, 1997) pada imago serangga E. thrax. Namun demikian, perlu adanya penelitian lebih lanjut tentang sebab-sebab ketidak beradaan bakteri ini di dalam tubuh E. thrax.

\section{SIMPULAN}

Dari hasil penelitian dapat disimpulkan bahwa $E$. thrax mempunyai potensi untuk menyebarkan bakteri penyebab penyakit darah pisang (Blood Disease Bacterium) yang dibuktikan dengan ditemukannya bakteri ini pada bagian kaki, sayap, permukaan kepala, dalam kepala dan permukaan tubuh serangga tersebut. Namun, Blood Disease Bacterium (BDB) ternyata tidak ditemukan di bagian dalam tubuh imago E. thrax (termasuk torak) dan larva E. thrax (baik di permukaan tubuh ataupun dalam tubuh larva).

\section{SANWACANA}

Penulis mengucapkan banyak terima kasih kepada Prof. Dr. Ir.. Eddy Mahrub, M.Sc. (alm), Suputa, S.P., M.P., Bpk Winarno, Bpk. Sarjiman, Rina Ediati, S.P atas semua saran dan bantuan yang telah diberikan.

\section{DAFTAR PUSTAKA}

Anonimous. 1991. Kunci Determinasi Serangga. Kanisius. Yogyakarta.

1971.Pests Control In Banana (Pans manual no 1).PANS 56 Gray's Inn road.London WCIX 8 LU. England.

Borror, D.J, D.M De-Long \& C.A Triplehorn. 1981. An Introduction To The Study Of Insects. Sounders College Publishing.

Buddenhagen I \& A. Kelman. 1964. Biological and Physiological Aspects of Bacterial Wilt Coused by Pseudomonas solanacearum. Annual Review of Phytophatology vol 2. Annual Review Inc. Palo Alto California p 203 - 226.

Fahy, P.C \& A.C. Hayward. 1983. Media and Methods for Isolation and Diagnostic Tests in : P.C. Fahy \& G.J. Persley. Bacterial Disease A Diagnostic Guide. Academic Press. Australia.

Kalshoven, L.G.E.1981. The Pests Of Crops In Indonesia.PT Ichtiar Baru-Van Hoove.Jakarta.

Maryam, A.B.N, T. Rasta, W. Handayati \& D. Sihombing. Akuisisi dan Persistensi Bakteri Layu Pada Tanaman Pisang Oleh Serangga. 1997. Prosiding Seminar Nasional Perhimpunan Entomologi Indonesia (PEI). 8 Januari 1997. Bogor p154-161.

Mau,R.F.L \& J.L.M Kessing. 1993. Pelopidas thrax (Linnaeus). http//:www. extento. hawaii. edu/ 
kbase/ crop/ Type/ Pelopida.htm diakses tanggal 5 Desember 2005.

Rukmana, R. 1999. Usaha Tani Pisang. Kanisius. Yogyakarta.

Schaad, N.W, J.B Jones \& W. Chun. 2001.. Laboratory Guide For Identification of Plant Pathogenic Bacteria.APS Press.Minnesota.

Subandiyah,S, S. Indarti, T Harjaka, S.N.H Utami, C. Sumardiyono, \& Mulyadi. 2005. Bacterial Wilt Disease Complex Of Banana In Indonesia. In : C. Allen, P. Prior, A.C. Hayward. Bacterial Wilt Disease and The Ralstonia Solanacearum Species Complex. APS Press. St. Paul. Minnesota U.S.A.
Sunarjono, H, Ismiyati, S. Kusumo \& Wardah.1989. Produksi Pisang Di Indonesia. Pusat Penelitian dan Pengembangan Hortikultura .Jakarta.

Supriadi. 2005. Present Status of Blood disease In Indonesia. In : C. Allen, P. Prior, A.C. Hayward. Bacterial Wilt Disease and The Ralstonia Solanacearum Species Complex. APS Press. St. Paul. Minnesota U.S.A.

Suspendy, R.2001.Potensi Beberapa Jenis Serangga Dalam Penyebaran Penyakit Layu Bakteri (Ralstonia Solanacearum) Pada Tanaman Pisang.Prosiding Perspektif Pembangunan Pertanian dan Kehutanan Tahun 2001 ke Depan (Buku II). Pusat Penelitian Badan Penelitian dan Pengembangan Pertanian. 